Volume3, Number 2, December 2005, pp. 1 13

\title{
Network Performance Measurement, As Appplied To Maritime Ports Communities
}

\author{
Charles-Henri Fredouet" and Patrick Le Mestre**
}

\begin{abstract}
Implementations of inter-organizational networks are common, following a growing diversity of cooperative modes between the independent companies associated in these networks.

Their scientific analysis has recently intensified, attention to network structures obviously including the study of the way their performance can be measured.

Although academic research has mostly dealt with the performance of the network's members, the concern of this article is rather with the performance of the global network.

Among the numerous forms of existing inter-organizational networks, maritime port communities are complex organizations which have to deal with operational synchronization, strategic cohesiveness and global performance measurement problems.

This article therefore mainly describes a port performance measurement system (PPMS): built in a predominantly empirical research context, the performance model and the associated measurement indicators illustrate the kind of networklevel dedicated, performance control systems, on which port communities need to rely when designing their global strategy.
\end{abstract}

Key words: decision support systems, organizational performance, logistics networks, sea-port management.

Submission Date : 6/2/2005 Acceptance Date : 11/15/2005

"Corresponding Author : Professor, Université du Havre (ISEL), quai Frissard, 76600, Le Havre, France, Tel:+ 332327449 07/00, Fax: + 332327449 11, E-mail : chf@univ-lehavre.fr

${ }_{*}^{*}$ Professor, Université de Nantes (IUT), rue Michel Ange, 44600, Saint-Nazaire, France 


\section{INTRODUCTION}

While the actual implementations of inter-organizational networks may be common, the scientific analysis of them however has only recently intensified. In addition, the concept of common-purpose independent-firms networking now stands at the crossroad of multiple schools of thought in the fields of economic and management sciences. The growing diversity of cooperative modes between independent companies leads to the blurring of inter-organizational frontiers, with inevitable consequences in terms of strategic and operational control (Yahiaoui, 1999): within the network co-exist individual strategies and organizations as well as a common strategy and a collective organization (Leyronas, 1999).

As, like so many say, “you can't manage what you can't measure", no goal formulation nor resource allocation, and therefore no network control, can be achieved without the availability of a network-level performance measurement system: even if the global performance of a network depends upon the individual performances of its constituents (Corrégé, 1999), it also results from the quality of the coordination performed between deeply entwined activities (Mévellec, 1990).

Among the numerous forms of existing inter-organizational networks, maritime port communities bear in France, as in many other countries, major operational and strategic control constraints (Frédouët \& Guérin, 2002): both a node of growing importance within inter-continental supply-chains and the most sought-after settlement of expanding import/export operations, the maritime port retains a wide variety of independent operators all contributing to a common value chain of logistics service providings (Bescos \& Mendoza, 1994). Such a complex organization has to deal with operational synchronization, strategic cohesiveness and global performance measurement problems (Paché, 1996).

Within a network performance measurement frame, this paper, based on a case study of the Port of Le Havre, France, then aims at describing a comprehensive model dedicated to the measurement of maritime port global performance.

\section{The Research Frame}

Attention to network structures obviously includes studying the way their performance can be measured. In the case of maritime port communities, specific strategic and operational processes have then to be taken into account.

\section{1. network performance}

Network performance is an ambiguous concept: does it means the performance of the network itself; or the performance of the network's members?

Academic research has mostly dealt with this latter version (Philippart, 2001). Qualitative measures (e.g.: members' mutual satisfaction or operational perceived performance (Mohr \& Spekman, 1994; Brok \& Barclay, 1997; Dumoulin, Meschi \& Uhlig, 2000)), as well as more quantitative ones (e.g.: ROI (Duncan, 1982)), or, within logistics networks, cost reduction or service rate enhancement (Dumoulin, Meschi \& 
Uhlig, 2000), have been designed.

Our concern is with the performance of the global network. This set of collaborative actors is surrounded by a specific frontier with 'an outer marke't. Therefore, the performance control system must measure not only the performance of each of the actors involved, but also that of the network itself, with respect to such outside stakeholders as the customers/consumers, the public/private investors and the state/local public administrations.

Besides traditional financial criteria, which account for only a part of the performance model, global network performance may be analyzed through its causal factors (Glaister \& Buckley, 1999; Harrigan, 1998; Killing, 1982; Kanter, 1994), or from such standpoints as the network survival (Killing, 1983; Geringer \& Woodcock, 1995), its life length (Harrigan, 1998; Spekman et al., 1996), or, in a more subjective and network-type constrained way, its own CEOs' evaluation (Dussauge \& Garrette, 1995).

The global performance measurement system reports on three different types of activities:

1) those conducted by the various actors involved, and which actually fall within their specific, and awaited for, contribution to the network processes.

2) those totally or partially conducted by individual actors, but which would be performed at company-level in the case of an integrated organization.

3 ) those conducted by the network itself, acting as an autonomous entity, and which actually are network-level activities.

The system consists of:

- specific sets of criteria, each one modelling the kind of performance achieved in a given activity (performance model).

- groups of performance indicators, each one associated with given set of criteria (performance measure).

In order to illustrate the design process of such a network performance measurement system, maritime port communities are attractive: those communities are made of many independent organizations, which co-operate within ship-centric and/or goods-centric processes. Would it only be at the operational level, their performance may then be analyzed on a global basis. Moreover, as maritime ports are increasingly interacting with their socio-economic environment, new dimensions appear in their performance model, which have to be taken into account when designing some kind of network-level management control system.

\section{2. maritime port community}

Port operations are performed within multimodal transport chains in which maritime ports stand at the junction between seaway transportation and pre-/post- land haulage and intermodal connectors.

Maritime ports can also be considered as virtually closed places where, from their arrival until their departure, goods may be moved, (re)-packed, or even transformed through post-manufacturing or value added operations. 
Therefore, each port's mission achievement needs effective and efficient interrelationships between all members of the port community. This community may then be taken as a network of independent companies tightly co-operating through multiple formal and informal collaborative agreements (Baudry, 1992).

Further qualification of a maritime port community requires defining more precisely under what type of network this set of inter-organizational relationships specifically fall.

Probably one of the network types which port communities best look like, is "a districtlike organic territorial organization" (Frédouët \& Guérin, 2002). This kind of network relies on long time local knowhow, from which the port community derives a strong collective identity, and which supports most of the processes performed by the numerous members of the community. These often are highly specialized SMEs, inter-related through a dedicated information system in a co-opetitive (mixed competition and cooperation) context (Brandenburger, Nalebuff \& Brandenburger, 1996).

Obviously, in the case of the main French maritime ports (e.g.: Le Havre), one member of the network is predominant: the state-representative so-called "Port Autonome", dedicated to such network-level activities as ship and goods security, state-owned land management or the maintenance of port infrastructures. This kind of port community may then be compared with a cybernetic, rather than an organic, network, within which the Port Autonome would stand as the leading firm in charge of at least partially co-ordinating all other members' actions in order to achieve network strategies.

However, even if the Port Autonome is best positioned to have a global vision and understanding of the port community, and to hold some decision or control power over various port activities, it actually stands neither as the strategic leader nor as the operational co-ordinator of the network of actors.

Therefore, port communities are essentially made of many independent organizations, each allocating all or part of its resources to ship- and/or goods-servicing activities. Those activities combine into logistics processes, the operational performance of which must be specifically and precisely evaluated, in an increasingly inter-port and inter-modal competitive context.

Moreover, the tighter the links between the port community and its local and regional environment are, the wider is the scope of the port performance. Beyond purely operational criteria, the performance reaches socio-economic dimensions, as, for example, port-related job creations and value-added activities have a direct and positive impact on surrounding social and economic development.

\section{PPMS: A Port Performance Measurement System}

Within a network of companies, the resources of which are wholly or partially dedicated to the satisfaction of common customers/consumers, operational and strategic activity management requires that the control system be designed at the global network level (Frédouët, Le Mestre \& Baert, 2000).

In order to craft such a performance measurement system for a port community, a twostep methodology has been followed:

- first, process- and performance-oriented information was gathered from a sample of 
local (port of Le Havre) operators and stakeholders.

- then, the actual design of the port performance measurement system (PPMS) was conducted.

\section{1. building the case-study}

For easier use and better understanding, most of the information gathered within the port of Le Havre community has been translated into "activity-resource" combinations.

\subsection{1 information gathering}

Two groups of actors have been interviewed:

1) a set of organizations deeply concerned with port global performance: local and regional public administrations, the local chamber of commerce, and the local economic development agency. Interviews have focused solely on these organizations' expectations with respect to port performance, therefore leading to the identification of their specific performance criteria and proposed measurement indicators.

2) a set of physical flow and/or informational flow operators, involving among others piloting and towing service providers, stevedores, transit agencies, Port Authority or French Customs. Here, interviews aimed at gathering the information required by the design of an "activity-resource" model of the port community:

- detailed information on the activities conducted by each operator. Some account for its specialized contribution to the port chain of logistic activities; others may be network-level activities at least partially performed by the operator.

-detailed information on the resources allocated to these activities. Knowledge of what, how much and how resources are implemented by each of the port operators is all the more important as a greater number and a wider variety of these operators contribute to a single activity within the global network.

\subsection{2 "activity-resource" combinations}

First, information gathered from the interviews has been recorded in a database. Then, thanks to this information, an "activity-resource" matrix has been built for each typical port operator. Finally, a global "activity-resource" model of the port network of actors has been designed as shown in Table 1: 
Table 1

\begin{tabular}{|c|c|c|c|c|c|c|c|c|c|c|c|}
\hline & 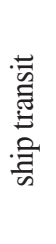 & 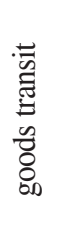 & 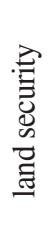 & 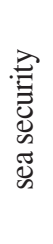 & 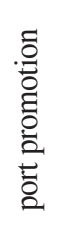 & 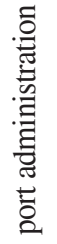 & 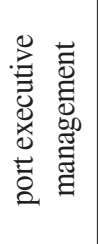 & 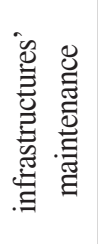 & 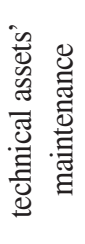 & 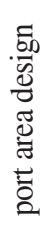 & 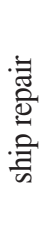 \\
\hline pilotage service & $\mathrm{X}$ & & & $\mathrm{X}$ & & $\mathrm{X}$ & & & $\mathrm{X}$ & & \\
\hline towing service & $\mathrm{X}$ & & & $\mathrm{X}$ & & $\mathrm{X}$ & & & $\mathrm{X}$ & & \\
\hline harbor services & $\mathrm{X}$ & & & $X$ & & $\mathrm{X}$ & & & $\mathrm{X}$ & & \\
\hline stevedoring & $\mathrm{X}$ & $X$ & $\mathrm{X}$ & & & $\mathrm{X}$ & & & $\mathrm{X}$ & & \\
\hline transit agency & & $X$ & & & & $\mathrm{X}$ & & & & & \\
\hline $\begin{array}{c}\text { ship } \\
\text { consignment }\end{array}$ & $\mathrm{X}$ & $\mathrm{X}$ & & & & $\mathrm{X}$ & & & & & \\
\hline brokerage & & $X$ & & & & $\mathrm{X}$ & & & & & \\
\hline Port Autonome & $\mathrm{X}$ & $X$ & $\mathrm{X}$ & $\mathrm{X}$ & $\mathrm{X}$ & $\mathrm{X}$ & & $\mathrm{X}$ & $\mathrm{X}$ & $\mathrm{X}$ & $\mathrm{X}$ \\
\hline IS company & $X$ & $X$ & & & & $\mathrm{X}$ & & & & & \\
\hline Customs & & $X$ & & & & & & & & & \\
\hline security agents & & & X & & & & & & & & \\
\hline dockyards & & & & & & $\mathrm{X}$ & & & & & $\mathrm{X}$ \\
\hline
\end{tabular}

Table lines indicate the scope of each typical (group of) actor's contribution to port activities and, therefore, its relative global weight within the port community. Table columns give a general description of the set of port activities, while at the same time accounting for each (group of) actor's inter-dependencies. As a whole, this "activityresource" model help identify two different types of activities:

1) operational activities, some actor-level ones, others (virtually) community-level ones, and performed by one or several actors:

- "actor-level" activities are conducted by port operators, as their specific contribution to the port operational processes (ship transit, goods transit), including commercial and accounting activities (port administration).

- "actor/community-level" activities are actually led by individual port operators, but could be managed at community-level: sea/land security, technical assets maintenance, and ship repair.

- "community-level" activities are performed by the Port Autonome, just like centralized functions would be in an integrated organization: port promotion, port area design, and infrastructures' maintenance. However, such a situation does not stem from a collective decision of all the community members to enact a common strategy in these three domains. It is only that other port 
operators have left community's major actor implicitly responsible for these activities.

2) the definitely network-level port executive management activity differs from all other activities, as, significantly enough, no resource is dedicated to its specific implementation within the port community.

However the following have been mentioned during the interviews as being truly at stake from a port executive management standpoint:

- optimizing short-term and long-term financial balances, through adequate profitability of the global network activity.

- designing health- and security-centric human resource management policies, as well as training and social negotiation processes.

- performing collective commercial actions towards selected markets (import/export geographic locations), customers (shippers, logistics service providers) and types of products/services (e.g.: refrigerated food products, container handling).

Interviews also made aware of the necessity, for the port network organization, to take its main stakeholders' constraints into account:

- cost, quality and timeliness of services provided, for port customers.

- job creation, security enforcement and environment protection, for local and regional public administrations.

- in-house short-term and long-term financial performance for each of the individual investors which are part of the port community.

Therefore, besides its financial side, port performance retains both managerial and socio-economic dimensions. For each of these specific criteria, mostly, although not exclusively, quantitative measurement indicators, must be identified.

\section{2. designing the PPMS}

Based on the port community "activity-resourc"e model, and the associated thoughts regarding the managerial and socio-economic dimensions of port performance, a port performance measurement system (PPMS) has been designed, through the combined definition of port performance criteria and identification of relevant key measurement indicators as illustrated in Figure 1: 
Figure 1

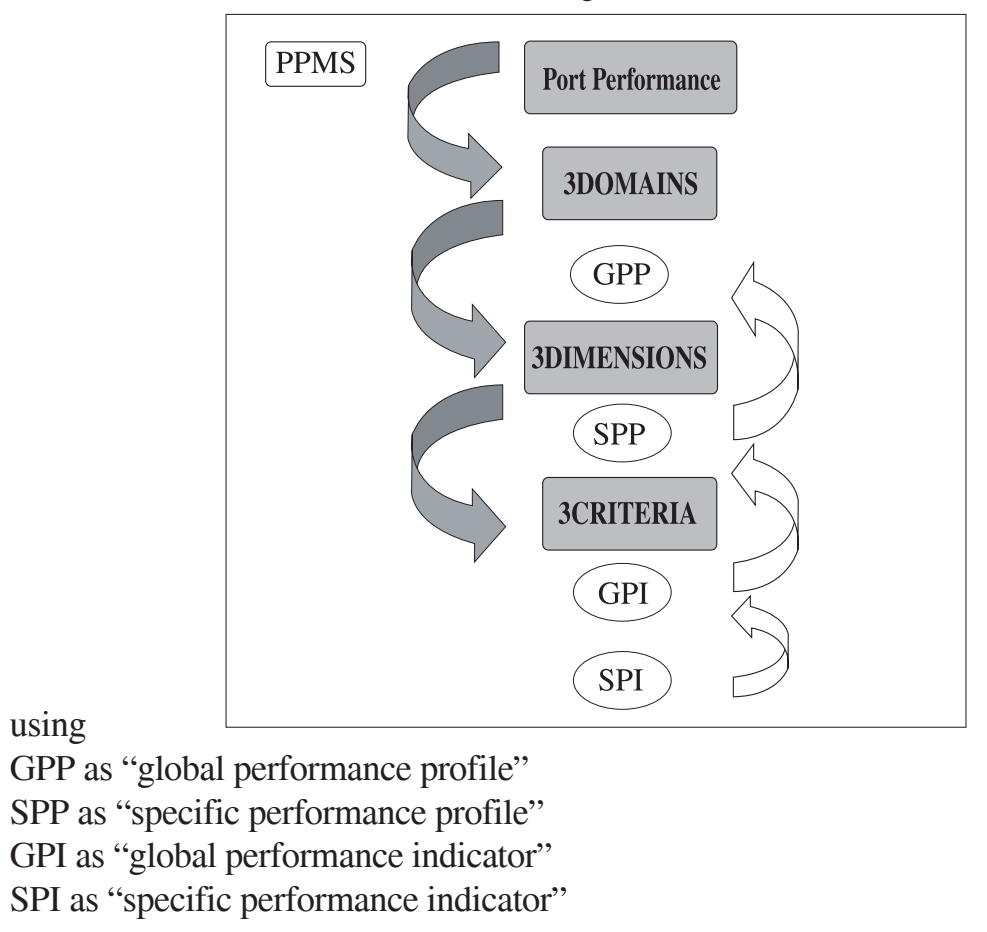

\subsection{1 port performance criteria}

They are drawn from the "activity-resource" model, where operational activities are split in three categories (actor-level, actor/community-level, community-level) and port executive management activity falls within managerial and socio-economic constraints. Port performance is therefore analyzed in three main domains: the operational, managerial and socio-economic domains. For each of these domains, three dimensions of performance have been defined. Finally, three basic performance criteria have been associated to each specific dimension as shown in Figures 2-4:

Figure 2

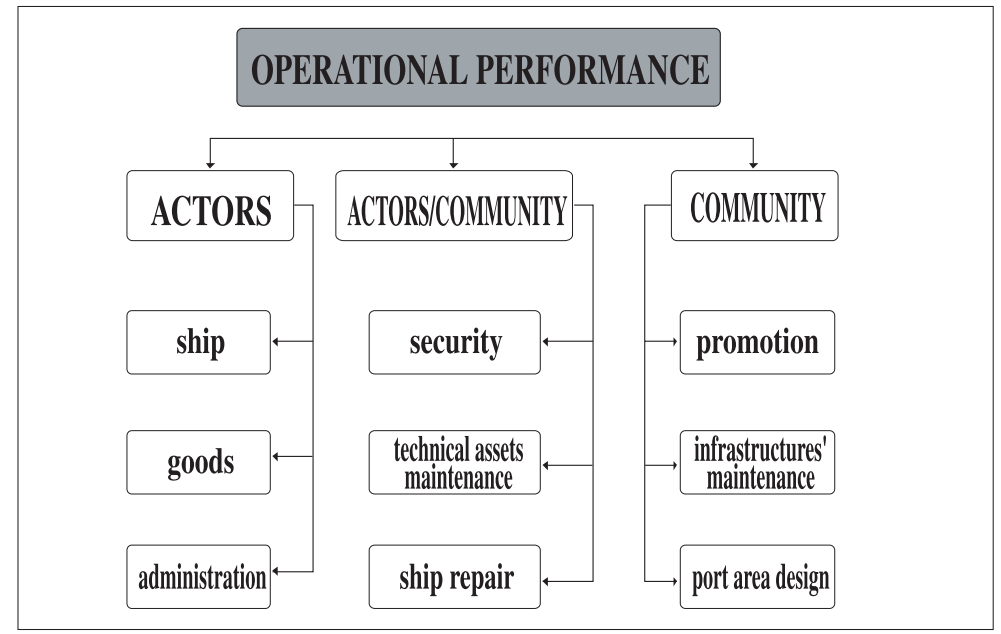


Figure 3

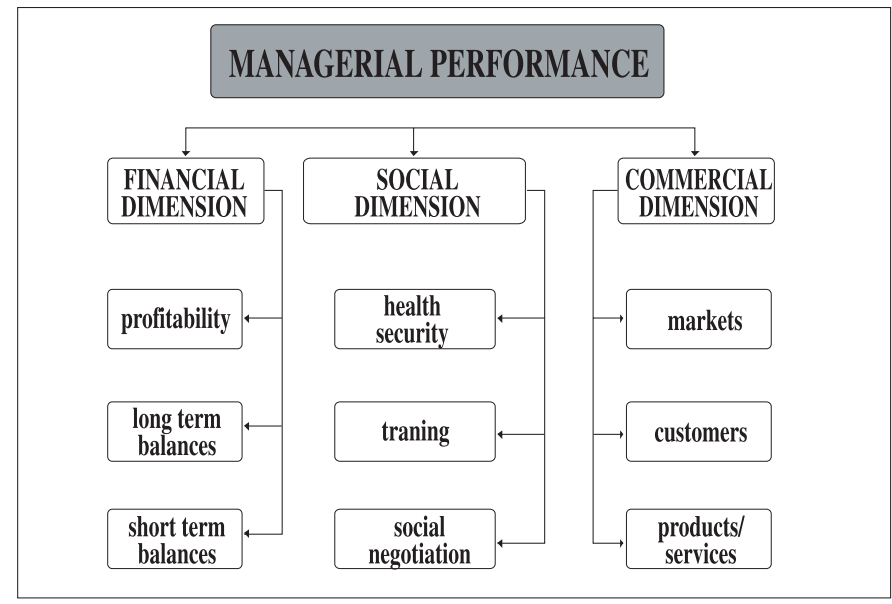

Figure 4

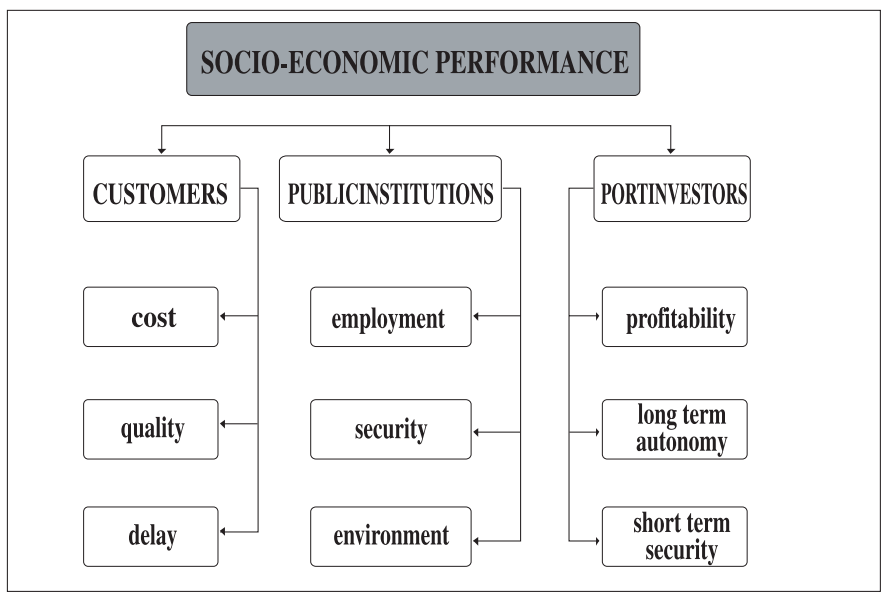

\subsection{2 key measurement indicators}

Key measurement indicators are basically specific performance indicators (SPI). Most of them have been drawn from generic global diagnosis processes (Frédouët, 1989), casestudies on port productivity (Robinson, 1999), and present trends in the design of performance measurement systems by various european port communities (Port of Rotterdam, 1999).

Inside the SPI database, each basic indicator is associated with 1) a basic performance criteria, and 2) a dedicated scorecard, where its present level, time-related variation and, if available, 'best in class' value are stored.

These SPI are then combined into global performance indicators (GPI) for the 27 performance criteria. The 9 dimensions of performance are measured through as many specific performance profiles (SPP). The same applies to the 3 main port performance domains, each being associated with a given global performance profile (GPP). 


\section{3. operating the PPMS}

Such a performance measurement tool may be operated in two different ways:

1) using common "drill-down" mode, to return the values of the indicators associated with the specific level of performance requested by the operator: for example, by displaying the values of all SPI associated with cost, quality and delay criteria, in the customer dimension of the socio-economic performance domain (Figure 5):

Figure 5

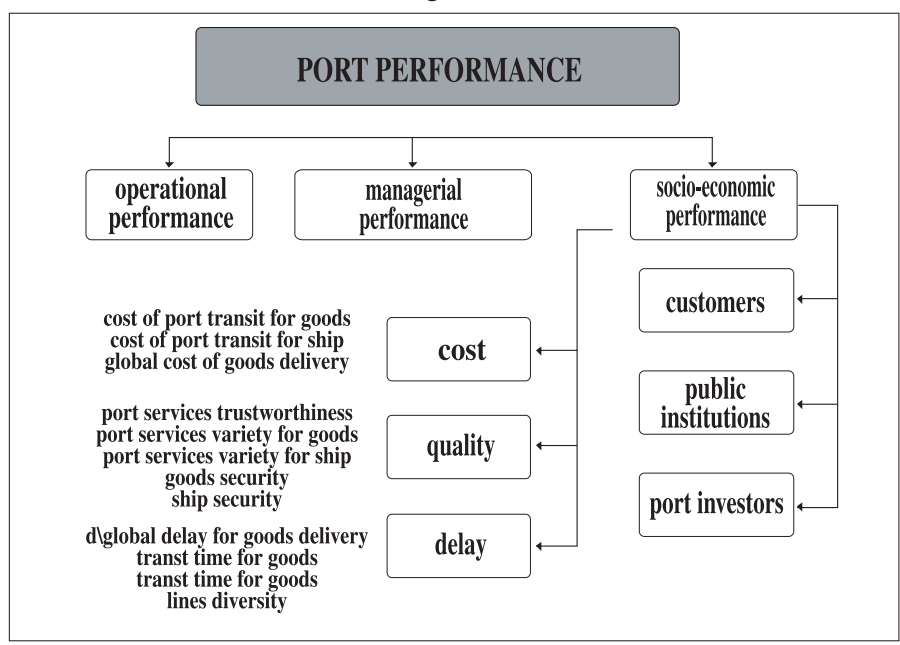

2) using a logical 3-circle structure, as shown in Figure 6, to compare the values of different criteria or dimensions indicators ; each circle retains the various criteria and dimensions of a given performance domain. The outer circle represents Socio-Economic Performance, the middle circle represents Managerial Performance, and the inner circle represents Operational Performance:

Figure 6

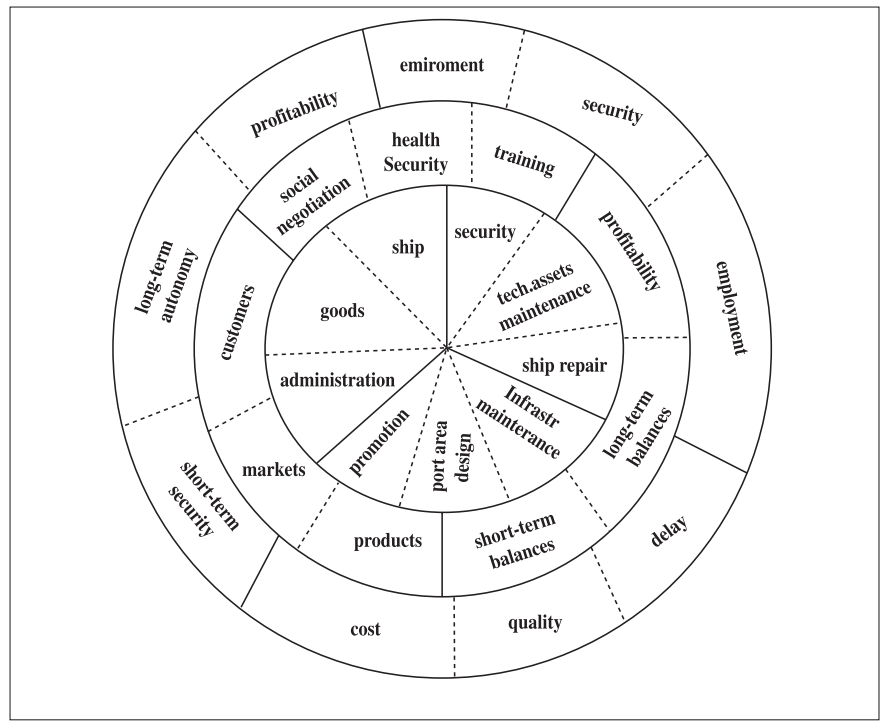


Requests to the measurement indicators database are then formulated by logically rotating the 3 circles to align the performance dimensions or criteria to be compared, as shown in Figure 7. e.g.:

"compare the profitability of the global port network (profitability criteria in the financial dimension of the managerial performance domain) with that of a given actor (profitability criteria in the port investors dimension of the socio-economic performance domain),"

"compare the efforts made to ensure port promotion (promotion criteria in the community dimension of the operational performance domain) with results achieved regarding port customers (customer criteria in the commercial dimension of the managerial performance domain),"

"measure the consequences of investments made in port area design (port area design criteria in the community dimension of the operational performance domain) on environmental issues (environment criteria in the public institutions dimension of the socio-economic performance domain),"

"measure the impact of improvements brought to goods transit operations (goods criteria in the actors dimension of the operational performance domain) on long term financial results of the global port network (long term balances in the financial dimension of the managerial performance domain) and on employment (employment criteria in the public institutions dimension of the socio-economic domain)."

Figure 7

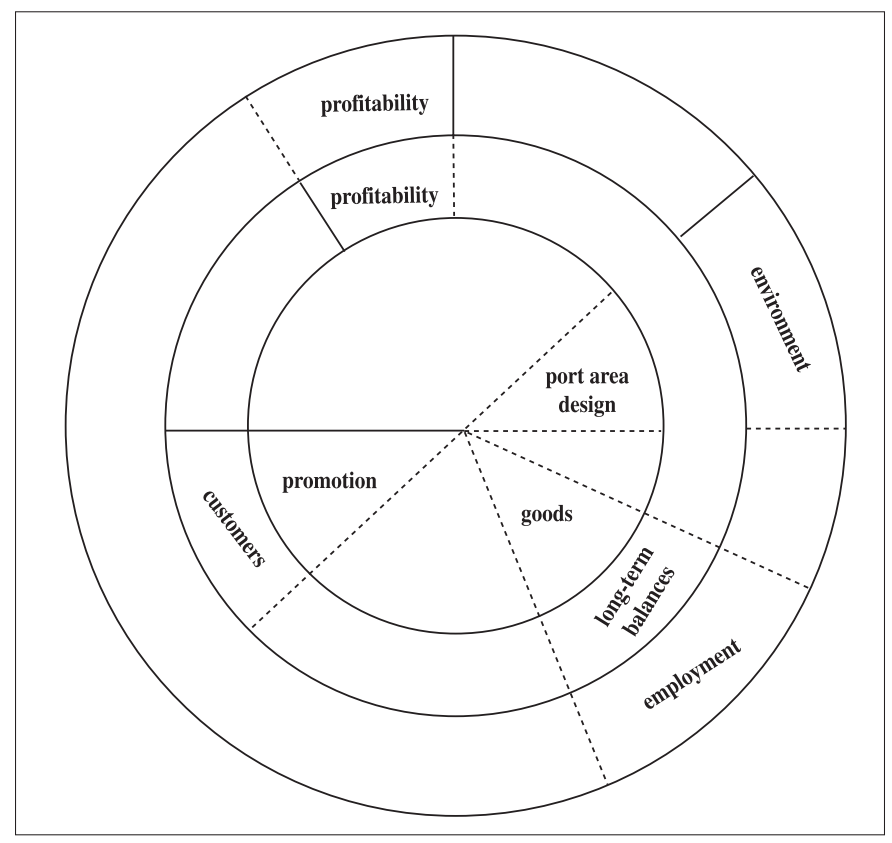




\section{CONCLUSION}

Our concern for network performance measurement, viewed from a port community standpoint, first led us to identify two levels of performance within a network: the actor's level and the network's level.

We also found that a port community could be considered as a (rather) non-centered network of independent flow operators and socio-economic stakeholders.

We could then sequentially describe:

- the "activity-resource" approach used when gathering data from the port of Le Havre community members and preparing PPMS design.

- the port performance model, split into three domains: the operational domain, the managerial domain, and the socio-economic domain, each of these domains itself being characterized by various basic performance criteria.

- the set of basic performance measurement indicators, combining first into criterialevel indicators, then into dimension-level and domain-level performance profiles.

- the system operating procedures, would it be under the drill down mode or through the proposed logical 3-circle interface.

Built in a predominantly empirical research context, this performance model and the associated measurement indicators illustrate the kind of network-level dedicated, performance control systems, which port communities could elaborate on a hopefully collaborative basis, and on which they need to rely when designing their essential global strategy.

\section{REFERENCES}

Baudry, B. (1992), "Contrat, autorité et confiance: la relation de sous-traitance est-elle assimilable á la relation d'emploi," Revue économique, 43/5, 871-894.

Bescos, P.-L. \& Mendoza C. (1994), Le management de la performance. (Paris: Editions Malesherbes).

Brandenburger, A.M., Nalebuff, B.J. \& Brandenburger, A. (1996), Co-opetition. (Doubleday).

Brok Smith, J. \& Barclay, D.W. (1997), "The Effects of Organizational Differences and Trust on the Effectiveness of Selling Partner Relationship," Journal of Marketing, 61/1, 3-21.

Corrégé, N. (1999), Dialogues autour de la performance en entreprise: les enjeux. (Paris: ECOSIP L'Harmattan).

Dumoulin, R., Meschi, P. \& Uhlig, T. (2000), "Management, contrôle et performance des réseaux d'ntreprises: étude empirique de 55 réseaux déalliances", Finance Contrôle Stratégie, 3/2, 81-112.

Duncan, L. (1982), "Impacts of New Entry and Horizontal Joint Ventures on Industrial Rates of Return," Review of Economics and Statistics, 64/2, 339-342.

Dussauge, P. \& Garrette, B. (1995), "Determinants of Success in International Strategic 
Alliances: Evidence from the Global Aerospace Industry," Journal of International Business Studies, 26/3, 505-526.

Frédouët, Ch.-H. \& Guérin F. (2002), Management portuaire: les nouveaux enjeux. (Paris: e-theque.com) [online] Available: http://www.e-theque.com (for a fee). [Accessed: 21st June 2005].

Frédouët, Ch.-H., Le Mestre. \& P., Baert, Ph. (2000), "Mesure de performance des chaînes logistiques: une application aux réseaux d'acteurs portuaires," presented at colloque supply-chain et nouvelles technologies: vers de nouveaux systémes d'offres, Bordeaux, France, 26th Oct.

Frédouët, Ch.-H. (1987), "Systémes-experts et diagnostic d'entreprise," presented at congrés national de l'AFC, Rennes, France, 12-13 March.

Geringer, J.M. \& Woodcock, C.P. (1995), "Agency Cost and the Structure and Performance of International Joint Ventures," in Chatterjee, K., \& Gray, B., (eds.) International Joint Ventures: Economic and Organizational Perspectives, Kluwer Academic, Norwell.

Glaister, K.W. \& Buckley, P.J. (1999), "Performance Relationships in U.K. International Alliances," Management International Review, 39/2, 123-147.

Harrigan, K.R. (1998), “Joint Ventures and Competitive Strategy," Strategic Management Journal, No. 9, 141-158.

Kanter, R.M. (1994), "Collaborative Advantage: the Art of Alliances," Harvard Business Review, 72/4, 110-120.

Killing, J.-P. (1983), Strategies for Joint Venture Success. (Praeger).

Killing, J.-P. (1982), "How to Make a Global Joint Venture Work," Harvard Business Review, 60/3, 120-125.

Leyronas, C. (1999), "Une analyse du fonctionnement des réseaux d'entreprises: La relation entre des petites entreprises et le réseau," Ph.D. thesis (France: Université de Montpellier-I).

Mévellec, P. (1990), Outils de gestion - La pertinence retrouvée. (Paris: Editions Comptables Malesherbes).

Mohr, R.J. \& Spekman R.E. (1994), "Characteristics of Partnership Success: Partnership Attributes, Communication Behavior and Conflict Resolution Techniques," Strategic Management Journal, 15/2, 135-152.

Paché, G. (1996), L'entreprise en réseau entre mythes et réalités. (Paris: Gestion 2000).

Phillipart, P. (2001), "La gestion des alliances interentreprises: précision des enjeux á partir d'une revue de la littérature ordonnée en trois pôles de problématiques," in actes de la Xéme conférence de l'AIMS, Université Laval, Québec, 13-15 Jun.

Port de Rotterdam (1999), Attention for Nature and the Environment in the Rotterdam Port. (Rotterdam, Port of Rotterdam) [online] Available: http://www.portofrotterdam.com [Accessed: 11th March 2004].

Robinson, D (1999), Measurements of Port Productivity and Container Terminal Design, Cargo Systems report, London, IIR Publications Ltd.

Spekman, R.E., Isabella, L.A., Macavoy, T.C. \& Forbes, T. (1996), "Creating Strategic Alliances which Endure," Long Range Planning, 29/3, 346-357.

Yahiaoui, F. (1999), Dialogues autour de la performance en entreprise: les enjeux. (Paris: ECOSIP L'Harmattan). 
